\title{
Building blocks of religion: Music, dance, songs and stories
}

\section{Author:}

Izak J. Spangenberg ${ }^{1}$ (1)

\section{Affiliation:}

${ }^{1}$ Department of Biblical and Ancient Studies, College of Human Sciences, University of South Africa, Pretoria, South Africa

\section{Corresponding author:} Izak Spangenberg, spangijj@iafrica.com

\section{Dates:}

Received: 28 Apr. 2021

Accepted: 27 May 2021

Published: 16 July 2021

How to cite this article: Spangenberg, I.J., 2021, 'Building blocks of religion: Music, dance, songs and stories', HTS Teologiese Studies/Theological Studies 77(3), a6784. https://doi.org/ 10.4102/hts.v77i3.6784

\section{Copyright:}

C)2021. The Authors. Licensee: AOSIS. This work is licensed under the Creative Commons Attribution License.
Socio-anthropological studies support the conviction that religion originated during the hunter-gatherer phase of Homo sapiens' existence. This phase is dated between 50000 and 15000 years ago. The hunter-gatherer religion evolved into agricultural religion when small communities settled down and started practising agriculture around 10000 years ago. This religion then evolved into city-state religion and the city-state religion eventually evolved into imperial religion. Looking at these four types of religion, it is possible to identify a few 'building blocks' which assisted the different societies in developing their religion, or better, for religion to evolve in tandem with the changes in society. It is argued that the Bauplan of the religions changed as the societies changed although the building blocks remained more or less the same. Music, dance, songs and stories are identified as the important building blocks of religion. An evolutionary perspective informs the historical overview of research concerning religion.

Contribution: Although the Bauplan of religions change when societies change, the building blocks remain the same. Music, dance, songs and stories are identified as important building blocks of religions. It is especially stories that contribute to the formation of a new religion and to the coherence of the new society.

Keywords: society; religion; Bauplan; building blocks; music; dance; songs; stories; historical consciousness; sociological consciousness.

Instead of believing ourselves to have been made in the image of a divine being, we find we are earthly organisms who have evolved biologically on this planet and then proceeded to create our cultures. (Geering 2009:31)

\section{Introduction}

There is a well-known cartoon with a baby dinosaur walking next to its mother whilst having a conversation concerning the subject of God's existence. ${ }^{1}$ The baby asks its mother, 'Mother, does God exist?', and the mother replies 'Not yet, my son'. The answer implies that human beings still have to evolve for the notion of gods to be born. ${ }^{2}$ Some readers may find the answer offensive but it communicates an important truth: the belief in gods, the worship of gods, the building of sanctuaries and temples and the creation of religious texts only commenced after Homo sapiens entered the scene around 200000 years ago. Without modern humans, none of these would have existed on earth. In the words of the Dutch theologian Harry Kuitert (1924-2017): 'Eerst waren er mensen en toen God' (Brinkman \& Vijver 2004:9). ${ }^{3}$

Kuitert was not the first to formulate this wisdom but the German philosopher Ludwig Feuerbach (1804-1872). He stated that 'God is the creation of human beings, not vice versa' (cf. Kennedy 2006:105). This conviction has become almost common knowledge amongst academics in the Western world and South African scholars are no more hesitant to argue along these lines (cf. Du Toit 2020; Viviers 2008). The fear of being labelled a heretic or being excommunicated has dwindled since the change in government in 1994.

For religion to come into being, hominins had to gain conscious brains slightly different from other mammals. Moreover, they had to develop the urge to understand their environment and to interact with it. This urge to understand and to interact with the environment found its expression

1.Nicholas Wade's narration (2010) of how religions change when societies change convinced me that music, dance, songs and stories are the basic 'building blocks' of religion.

2.The cartoon sometimes depicts a baby dinosaur hatching with a father dinosaur watching. The conversation, however, remains the same. 3.It can be translated as 'There were first humans before there were gods'.

Note: Special Collection: Challenging Building Blocks, sub-edited by Chris Jones (Stellenbosch University) and Juri van Heever (Stellenbosch University). 
inter alia in stories, songs, paintings, drawing, sculptures, buildings and many more. The earliest evidence of human art is the so-called 'Blombos engraved ochre' (Palmer 2007:67, 87). It is a rectangular engraved ochre stone found amongst the Blombos cave deposits dated between 100000 and 70000 years. If this is the earliest evidence of human art and of symbolic expression, then one may argue that religious expression also started during this period because symbolic expression and religious expression are two sides of the same coin. Religions may also be defined as cultural expressions of humans: how they understand themselves and how they interact with their environment.

This article endeavours to identify the building blocks of religions by looking at published material concerning the origin and evolution of religions. However, it will focus primarily on Early Judaism and Christianity.

\section{Historical consciousness}

Some scholars opine that one should not apply the notion of evolution which Charles Darwin (1809-1882) developed for biological studies to other fields of study, especially not to religious studies (Du Toit 2009:1-14). According to them, it constitutes the abuse of a theory that originated in the field of biological research and should only be reserved for that field because the aspect of 'natural selection' is only applicable to biological studies. However, as evolution has to do with change over time, and change can be identified in all fields of study, one may use the words 'evolve' and 'evolution' when discussing changes in religious beliefs and practices.

Darwin formulated the theory of evolution by means of natural selection to explain how species change over time and how all life forms on earth that ever existed and currently exist hang together. He actually avoided the term 'evolution' and preferred to talk about 'descent with modification' (Weinert 2009:115). What Darwin did was to allow his historical consciousness to influence his biological research. He took a keen interest in geology whilst studying at Cambridge University and read the books of the geologist Charles Lyell (1797-1875) during his voyage on HMS Beagle. During those years, geologists became increasingly convinced that the earth's surface changed over millions of years ago and that the rocks gave evidence to the processes that caused the changes. Geologists soon came to be called 'historians of the Earth' (Rudwick 2012:84). Darwin eventually became convinced that a historical perspective was all important for the study of biology as well. Scholars working in other fields of research soon followed suit and allowed their historical consciousness to influence their fields of research. The notion of 'change over time' assisted many in coming to grips with the conviction that nothing on earth remains the same - not even humans, their culture and their religions. Change is inevitable.

\section{The dawn of historical consciousness}

Before the 18th and 19th centuries, Europeans did not possess a well-developed historical consciousness. This is evident when one studies the paintings of famous European artists like Rembrand van Rijn (1606-1669) who lived in the 17th century. In his paintings with biblical themes, he dresses the characters in the clothes of contemporary Dutch people. His etch of David and Goliath may serve as an example (Van Rijn 1655).

David wears the clothes of a young Dutch boy, whilst Goliath's battle dress is that of a soldier living in the 17th century. However, archaeological excavations in Egypt during the 19th and 20th centuries revealed that the Philistines did not wear that kind of battle dress. Their battle dress looked totally different (Noort 1994:60-61, 64-65). Van Rijn unconsciously erred and created an anachronistic picture of the biblical story. Living in the 17th century, he did not possess a well-developed historical consciousness.

During the 18th and 19th centuries, scholars such as George Wilhelm Friedrich Hegel (1770-1831), Barthold Georg Niebuhr (1776-1831), Leopold von Ranke (1795-1886) and Johann Gustav Droysen (1808-1884) contributed to the change in how Europeans understood history and the dates that were given to past historical events (Woolf 2012:332-340). Prior to these scholars, people believed that the chronology compiled with the aid of the Bible was $100 \%$ correct. Moreover, they believed that the earth was created 4004 years before the birth of Jesus Christ on account of Archbishop James Ussher's calculations (Barr 2013:375-379). However, new discoveries challenged the old views and historians developed new methods of studying past events and of writing critical history. Historical studies eventually developed into a proper human science.

\section{Historical consciousness and uniformitarianism}

A historical consciousness is an awareness that the world of humans who lived in previous centuries looked totally different from ours. Moreover, those people had a different world view and a different understanding of the cosmos and how the sun, moon and earth relate to one another. Their clothes, furniture, vehicles, houses, utensils and cities looked different and confirmed that their culture was not similar to ours. A historical consciousness compels one to acknowledge that the past is not merely a different place, but it is a totally different world. Pattison (1998:35) summarises this well when he writes about the strange world of the Bible: 'The first and twenty-first centuries are divided by precisely twenty centuries, twenty centuries of continual and colossal change'.

Geologists did not only develop a well-informed historical consciousness during the 18th and 19th centuries, but they also developed a concept called 'uniformitarianism'. Uniformitarianism is the conviction that the same natural forces that currently operate on earth operated in the past as well (Skinner \& Murck 2011:104-105). There were water, snow and wind that caused erosion. There were volcanoes, earthquakes and tsunamis. The moon was responsible for tides and the sun for energy, warmth and ultraviolet rays. 
Asteroids and meteorites struck the earth fairly often and caused damage. Gravity existed then as now. There were no divine acts that caused the moon or the sun to 'stand still' as narrated in Joshua 10. Nor ones which could cause a worldwide flood as narrated in the story of Noah (Gen 6-9). Scholars became convinced that the natural forces on earth did not change over time nor the different sub-systems responsible for the way the earth system functions (Skinner \& Murck 2011:5-22).

\section{Historical consciousness, the study of the Bible and religions}

The dawn of a historical consciousness in Europe impacted all fields of study, be it geology, biology, theology and religious studies. In theology, it had a major impact on the study of the Bible. The so-called historical-critical method was born and caused a major change in the way the Bible was read and understood (Kennedy 2006:118; Noll 1991:11-61). The authority of the Bible was consequently challenged and the traditional Christian doctrines as well. However, theologians and some anthropologists still reserved a special place for Christianity when compared to other religions. According to some scholars, Christianity was not merely a human cultural product like other religions, but it was a 'revealed religion'. Christians believe that the Christian religion is based on divine revelation. In the words of Karl Barth (1886-1968) - one of the exponents of this viewpoint - it was a revelation straight from above ('Göttliche Offenbarung senkrecht vom oben' (Barr 1973:18-22).

Edward Tylor (1832-1917), a British anthropologist who was convinced of the superiority of monotheism, developed the following evolutionary account of the religions (see Figure 1).

According to this understanding, the monotheistic religions ranked higher than all the other forms of religion. There was thus a progressive change from the belief that natural objects such as trees, animals, rivers and rocks have a 'soul' which

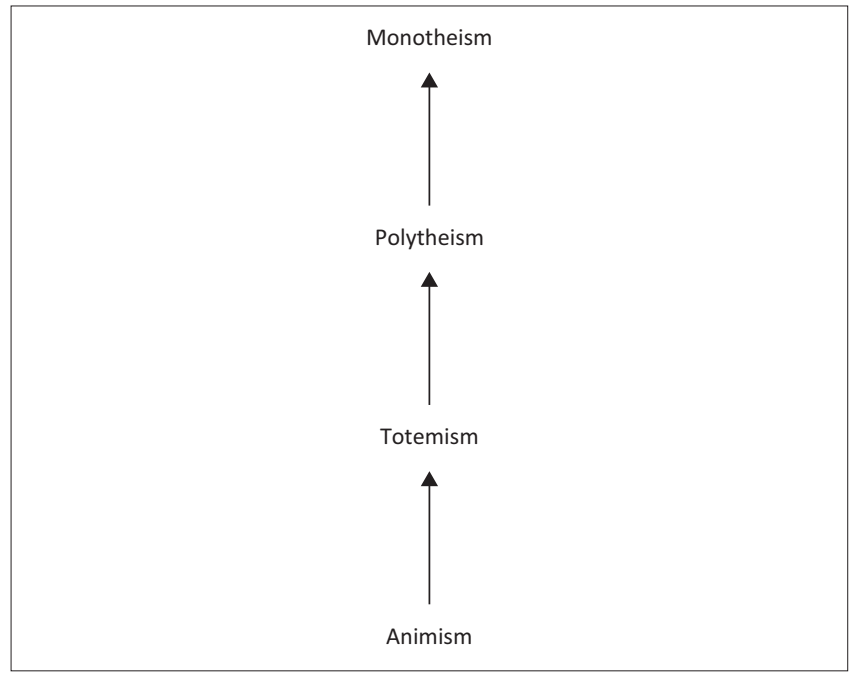

Source: Lewis-Williams, D., 2010, Conceiving God: The cognitive origin and evolution of religion, Thames \& Hudson, London.

FIGURE 1: Edward Taylor's evolutionary account of the religions. should be venerated to the belief that these objects symbolise the ' $\operatorname{god}(\mathrm{s})$ ' of the clan. This led to polytheism - the belief in many gods who were responsible for the well-being or the hardships of believers. Polytheism eventually evolved into monotheism that represents the highest stage in the religious development of humans. Theologians latched onto this conviction and argued that Christianity superseded Judaism and thus ranked the highest whilst Islam was seen as an 'aberration' of both Judaism and Christianity.

Uniformitarianism impacted on the understanding of the religious texts of the monotheist religions, and scholars argued that our present experiences of the world do not differ from the experiences of people living in ancient times. They may have interpreted their experiences differently but in essence the experiences were the same. As God does not speak audible today, he did not speak audible in the past. When an author writes 'The LORD spoke to Moses and said:' (Ex 25:1), it does not mean that the words following the colon should be regarded as the direct words of Yahweh. The words following the colon were the author's. He created the speech. One may thus say that God can only speak if the author constructs such a speech. This applies to the miracles as well. We know that water cannot miraculously be turned into wine. When the author of the gospel according to John tells a story concerning a wedding in Cana where Jesus turned water into wine (Jn 2:1-12), he is not telling history but a story - a story which he created and which is not rooted in real history (Fokkelman 1999:58-59). The story, however, communicated an important message to the readers of the gospel: the followers of Jesus are doing away with the ritual practices of Jews and are developing their own identity (Trocmé 1997:108-109).

\section{Sociological consciousness}

During the 18th and 19th centuries, Europeans not only developed a historical consciousness but also developed a sociological consciousness. The discovery of people living on other continents and islands during the 16th and 17th centuries led to the birth of a new discipline called sociology.

The French philosopher Auguste Comte (1798-1857) firstly used the word 'sociology' for the study of human societies. He believed that societies can be studied in the same manner in which other objects in the natural world are studied. However, philosophers and theorists who followed in his wake 'had a vision of using sociology to call attention to social concerns and bring about social change' (Crossman 2019). The following scholars may serve as examples: Karl Marx (1818-1883), Émile Durkheim (1858-1917), Max Weber (1864-1920), W.E.B. Du Bois (1886-1963) and Harriet Martineau (1802-1876).

The convictions these scholars expressed impacted the study of religion also because very few societies exist without religious beliefs (Wolpert 2008:120). Sociologist tried to understand why this is the case. Do religions play a role in the survival of a society? Most sociologists give a positive 
answer to this question. According to them, religions would not have survived if they did not serve the needs of a society. Durkheim, for example, was convinced that 'religion unites people into a single community' (cf. Lewis-Williams 2010:120; Wade 2010:115). He, moreover, did not rank the religions but argued that different societies merely gave expression to different religious beliefs. One may thus say that the Bauplan of a religion changes when the environment - the society in which it functions - changes. However, the building blocks of the religions remain the same. ${ }^{4}$

\section{Different societies - Different religions}

\section{Hunter-gatherer societies and the beginning of religion}

According to Wade (2010:45-52), religion originated in hunter-gatherer societies that existed between 50000 and 15000 years ago. Taking the evidence of the Blombos cave into account, one may argue that religion originated earlier than what is commonly accepted. ${ }^{5}$ The hunter-gatherer groups were larger than ape-like groups in which humans lived prior to the hunter-gatherer societies. The new societies needed something else than an alpha male to keep the group together. Communal singing and dancing, and the belief in a world different from the one members daily experienced, became all important for keeping the society intact. Long periods of singing and dancing led to the experiencing of trances. These experiences convinced members that there is another world where departed ancestors lived and one can enter their world with the help of trance experiences. Those who had such experiences were able to tell new stories about the ancestors and what they expected from the group. Singing, dancing, the experiencing of trances and storytelling soon formed the building blocks of the religion of the huntergatherer groups (Wade 2010:78-97). ${ }^{6}$

\section{Early agriculturalists and agricultural religion}

The hunter-gatherer societies were egalitarian because all could experience trances and not only specific members of society. This, however, changed when groups started to settle down and practise an early form of agriculture. This change occurred around 10000 BCE not only in the fertile crescent of the Ancient Near East but also in other parts of the world (Harari 2014:77-79, 98-101; Wade 2010:49). However, the hunter-gatherer religious practices could not fully address the new societal needs. Moreover, the agriculturalists had less time for singing, dancing, trance experiences and storytelling. They had to spend long hours working in their fields. They now had to pay attention to the weather and to the seasons. Specific months were reserved for planting, whilst others were reserved for harvesting. It also dawned on

4.The German word Bauplan is used in biological studies to refer to the "body design of an animal' (LeDoux 2019:111). Evolutionary biology emphasises that different species of animals have different Baupläne although the 'building blocks' remain the same. These concepts are helpful in describing what transpired during the evolution of religion.

5.Lewis-Williams (2010:207) is of the opinion that one should rather set the Blombos finds aside 'until we have a better idea of what was happening in the early periods of the southern African Stone Age'.

6.Although Wade does not emphasise storytelling, he is convinced that language became all important in the hunter-gatherer societies (Wade 2010:74-75, 87-90). them that the sun and moon played a role in the seasons, and this led to the veneration of these heavenly bodies and sometimes even to worship them as gods. The building blocks of the previous religion were soon put to new use. Singing, dancing and storytelling were reserved for the agricultural festivals celebrating each new season (Wade 2010:189). The Bauplan of the religion changed because the society changed but the building blocks remained the same.

There were no special groups of priests in the early villages because the religion of the early settlers was not that well developed yet. The local chief probably acted as a ruler and a priest. However, the village religion soon had to make room for city-state religion.

\section{City-states and city-state religion}

Villages were easy targets for roaming bandits. To protect themselves, village people had to erect fortified cities. With the establishment of bigger cities, a ruler class developed. 'External pressure from enemies or rivals necessitated a concentration of the power of command at one point' (Gerstenberger 2002:23). The ruler class consisted either of priests or of a local chief assisted by priests supporting his claim of being appointed by the gods to be the ruler. The egalitarianism of the huntergatherer groups eventually disappeared and the 'hierarchical side of human nature reasserted itself' (Wade 2010:125). Palaces and temples were built and the temple was often located next to the palace because politics and religion were closely related.

The priests organised the cultic practices in such a way that they monopolised the access to the spiritual world (Wade 2010:190). The rulers and priests of the city-states structured the society hierarchically. Anyone living either in or near these states were regarded as citizens who had to obey the city rulers' laws and regulations. Once again, the change in society affected the religion (Wade 2010:189). The priests convinced city-dwellers that the ruler class mirrors the heavenly pantheon. At the top of the pantheon were the supreme god and his consort - on earth represented by the king and his queen. Below them were their children who were lesser god and below them, still lesser gods who mirrored the palace personnel. Below them were the working class - in heaven represented by the angels. The hierarchy on earth was similar to the hierarchy in heaven. It was emphasised that the citizens should adhere to the social order and not disturb it because that could have dire consequences. ${ }^{7}$

A totally new Bauplan for the city-state religion came into being. However, the previous building blocks - music, singing and storytelling - were put to new use. There were temple singers, temple musicians and temple scribes - all playing their role in the functioning of city-state religion and in keeping the citizens subordinate and happy.

7.Gerstenberger devotes a chapter on how this change in society affected the Israelite religion (Gerstenberger 2002:161-205). 
The priests were responsible for sacrifices and for organising cultic festivals to praise, thank and honour the gods for their protection, for peace, fertility and prosperity. Citizens took part in these religious acts but they were more onlookers than real participants. This may be one of the reasons why family religion kept on surviving. At home, they could worship their family gods, sing and dance - keeping the family gods alive.

\section{Empires and imperial religion}

Some city-states joined other city-states, and soon a totally new political structure and society came into being the empire. The aim of these mergers was to lay hold on the natural resources in the region, the goods that were manufactured, the farming produce and even humans who could build storage houses and roads for travel and trade. Permanent armies came into being and they were tasked to maintain peace and stability within the borders of the empire. Most of the time, it was a powerful and charismatic ruler who forced city-states to merge or form a coalition. The acts of Alexander the Great (356-323 BCE) may serve as an example.

Philip II, father of Alexander, succeeded in merging the citystates of Macedonia. Alexander followed in his footsteps and merged the Macedonian city-states with the Greek city-states with the aim of invading and conquering the Persian Empire (Cline \& Graham 2011:142-148). Within 10 years, he succeeded not only to conquer the Persian Empire but also to lay hold on other regions, and in this way established the Hellenistic Empire of Alexander the Great. The Greek cultures were spread across the ancient Near East and once again religion - part of the Greek culture - contributed to enforcing unity. The Greek gods had to be venerated if not worshiped in the main cities of the empire by the subjugated peoples. There were revolts like the one the Jews staged in 164-167 BCE, but none was really successful. The Jews enjoyed independence for a few years but soon had to succumb to the Roman Empire (Horsley 2003a:80-81). They twice tried to regain their independence and fought two major wars against the Romans (66-70 CE and 132-135 CE) but never regained their independence (Horsley 2003b:35-37). Harari (2014) comments as follows concerning this aspect of empires:

Building and maintaining an empire usually required the vicious slaughter of large populations and the brutal oppression of everyone who was left. The standard imperial toolkit included wars, enslavement, deportation and genocide. (p. 193)

Any rebellion against an empire is usually brutally suppressed.

To keep the empire intact, the subjugated people had to buy into a myth (or myths) which the elite created and shared with them (Harari 2014:105-110). The myth of political and economical benefits has always convinced subjugated people to succumb and not to resist. A religious myth often supported the political myth. The gods of the empire are always better than the local or national gods. This is evident inter alia in the victorious battles the empire armies fought and won. And then there are benefits such as 'peace, justice and refinement' (Harari 2014:198).

\section{Baupläne and building blocks of Christianity}

The history of Christianity evidences some of the changes discussed in the previous sections. Christianity only started after the fall of Jerusalem and the Temple in 70 CE. The early Christians were Jews and they did not distinguish between themselves and other Jews. They went to the Temple and adhered to the Jewish convictions and practices. However, soon after $30 \mathrm{CE}$, a new group within Early Judaism came into being (Horsley 2003a:86-87). The group was followers of the Jewish prophet Jesus of Nazareth whom some saw as the Messiah of the end times. He died a tragic death on a Roman cross in $30 \mathrm{CE}$ because the rulers in Jerusalem interpreted his act of cleansing the Temple (Mk 11:15-18; Mt 21:12-17; Lk $19: 45-48)$ as the beginning of another rebellion which had to be suppressed.

After his death, some followers had spiritual experiences which they interpreted as reappearances of Jesus and stories about his resurrection and ascension were soon told (Mt 28; Lk 24; Ac 1:1-14). Some groups believed that Jesus' vision of the Kingdom of God will soon become a reality. Jesus will return to usher in God's Kingdom. Some leaders within the group argued a case that Jesus did not die in vain. According to them, his death and resurrection opened the door for nonJews to join the ranks of the movement and become the 'new Israel' (Luttikhuizen 2006:18-21,63-76). What made this new Jewish group and their convictions attractive was the fact that they worshipped only one God, cared for each other and did not expect newcomers to become Jews. No one had to be circumcised, adhere to the Jewish dietary laws and partake in Jewish festivals.

The early Christians evidently used the Bauplan of Early Judaism to develop their religion which they regarded as a true and trustworthy version of Judaism. Seeing that they could not worship in the Temple anymore, they met in houses where they prayed, sang and shared stories about Jesus Christ. They also believed that he would return to establish the Kingdom of God. The early Christians were evidently a Jewish apocalyptic group expecting the end times to arrive during their lifetimes (2 Th 2:1-12).

Quite a number of non-Jews joined the movement and soon changed its character (Trocmé 1997:99-112). Previously, it was a Jewish group within Early Judaism but it changed to a Graeco-Roman group that usurped the Jewish scriptures and interpreted them in totally different ways. The Jewish prophet Jesus of Nazareth was transformed into a god at home in the Roman world. The new religion that came into being was called 'Christianity'. The name refers to the conviction that Jesus was the Jewish Messiah (or the anointed 
one). ${ }^{8}$ Within three centuries, the new religion gained so many adherents that the Roman emperors had to take notice of them (Horsley 2003a:91).

In the 4th century, Emperor Constantine (275-337) decreed toleration for Christians and declared Christianity a legitimate religion of the empire. Judaism was already declared a legitimate religion of the empire centuries ago and some emperors took Christianity to be an aberration of Judaism not to be tolerated. Suddenly, Christianity stood on par with Judaism. A few decades later, Emperor Theodosius I (346-395) declared Christianity the sole official religion of the Roman Empire. The Jews were soon accused of deicide, whilst the Romans who were responsible for the crucifixion of Jesus centuries ago were absolved.

A new Bauplan for the religion developed. Prior to the 4th century, the Christians were practising a kind of 'family religion' similar to how Judaism was practised after the fall of the Temple in 70 CE. A new myth was created in which Jesus Christ played the same role as the emperors in the cult of the Roman emperors. He was now the saviour, "whose "gospel" of "salvation" and "peace and security" was publicly proclaimed' (Horsley 2003a:99). Titles that were previously used to refer to the Roman emperor were transferred to Jesus Christ. The Bauplan of the new imperial religion was similar to the Bauplan of the Roman imperial cult but the music, songs and stories were totally different. Christian theologians developed a story in which Jesus' original message was ignored. The message of Jesus was turned into a message about Jesus. In the words of Sullivan (2002:93), 'The church's gospel about Jesus is not the same as the gospel preached by Jesus'. This gospel story eventually morphed into a Grand Narrative of a fall, redemption and judgement which Christians still hold dear (Kennedy 2006:252).

Many New Testament scholars these days argue a case that Jesus' message of the Kingdom of God was a message subverting the claims of the Roman empire about peace, stability and prosperity. His message can be rephrased as follows: 'Should Jahweh rule in Palestine, the society in Palestine would be structured totally different and Jahweh's care for the hungry, the poor, the destitute would be visible'. This message was, however, overturned in the 4th century when Christianity became the sole imperial religion. Jesus used the traditions of Early Judaism to criticise and resist the Roman empire, but in the 4th century, the imperial Christian religion had to cement the imperial power relations (Horsley 2003a:91).

This imperial religion played a role not only in the Roman Empire of the 4th and later centuries but also in subsequent empires which came into existence in Europe and the Western world. Terreblanche (2014) identified two patterns of European empires. The first existed from 1530 to 1820, and the second from 1820 to 1950 . He characterised them and the ideologies they promoted as follows (Terreblanche 2014):
The ideologies propagated in the first pattern of European empires (1530-1820) were mainly based on the presumed superiority of European people, on the need to spread Christianity to the 'heathen' peoples in the non-European world, and on the illusion about rebuilding the universal Christian Roman Empire.

During the second pattern of Western empires (1820-1950), empire building was mainly justified by the alleged need to spread the rational and/or bourgeois civilisation of the Enlightenment to the backward, irrational and primitive peoples of the non-European world and by propagating racist ideas about the alleged biological inferiority of these people vis-à-vis the superiority of Europeans. (p. 124)

The European empires improved the life circumstances of many people across the world but this came at a price. The subjugated people had to give up their freedom, independence, religion, language and their natural resources. Many of them were transported to other regions of the empires and were sold to work as slaves in foreign countries. Currently, the world is still dominated by a Western empire - the American Empire (McCoy 2017; Northcott 2004; Vidal 2004) - and Christianity is still used and abused to keep the empire intact. In the words of Horsley (2003b:142), 'Especially striking to people from outside the United States is how fanatically religious American imperialism can be'.

\section{Conclusion}

The previous sections argued a case that change affects human societies and their religions. Furthermore, that although the Bauplan of a new religion may look different from the Bauplan of the religion out of which it evolved, the 'building blocks' remain more or less the same. The only difference between the new and the old is the way the 'building blocks' are utilised and filled with new content. One of the most important building blocks is the stories that are created and told. Humans cannot exist without a story that can guide them through life and let them feel at home in a world where bad thing happen to good people. Although Christianity is still influencing many people's lives through its Grand Narrative, it is evident that this religion is no more aligned with the needs of the global society of the 21st century. The global society is in dire need of a religion (or at least a story) that can assist humans to cope with the ecological crisis humans are facing and which the American empire is ignoring.

\section{Acknowledgements Competing interests}

The author declares that he has no financial or personal relationships that may have inappropriately influenced him in writing this article.

\section{Author's contributions}

I.J.S. is the sole author of this research article. 


\section{Ethical considerations}

This article followed all ethical standards for research without direct contact with human or animal subjects.

\section{Funding information}

This research received no specific grant from any funding agency in the public, commercial or not-for-profit sectors.

\section{Data availability}

Data sharing is not applicable to this article as no new data were created or analysed in this study.

\section{Disclaimer}

The views and opinions expressed in this article are those of the author and do not necessarily reflect the official position of any affiliated agency of the author.

\section{References}

Barr, J., 1973, The Bible in the modern world, SCM Press, London.

Barr, J., 2013, 'Why the world was created in 4004 BC: Archbishop Ussher and biblical chronology', in J. Barton (ed.), Bible and interpretation: The collected essays of James Barr, Vol. 2, pp. 375-379, Oxford University Press, Oxford.

Brinkman, M. \& Vijver, H., 2004, 'Inleiding', in M. Brinkman \& H. Vijver (eds.), Harry Kuitert: zijn God: Schrijvers, theologen en filosofen over de God van Kuitert, pp. 7-14, Ten Have, Kampen.

Cline, E.H. \& Graham, M.W., 2011, Ancient empires: From Mesopotamia to the rise of Islam, Cambridge University Press, Cambridge.

Crossman, A., 2019, 'The history of sociology is rooted in ancient times', ThoughtCo, viewed 19 April 2020, from https://thoughtco.com/history-of-sociology-3026638.

Du Toit, B., 2020, God: Is daar 'n ander antwoord? LAPA Uitgewers, Pretoria.

Du Toit, C.W., 2009, 'Is religion grounded in evolution? A critical look at some models', in C.W. Du Toit (ed.), The evolutionary roots of religion: Cultivate, mutate or eliminate, South African Science and Religion Forum, vol. 13, pp. 1-33, University of South Africa, Pretoria.

Fokkelman, J.P., 1999, Reading biblical narrative: A practical guide, Deo Publishing, Leiderdorp.

Geering, L., 2009, Coming back to Earth: From gods, to God, to Gaia, Polebridge Press, Salem.
Gerstenberger, E.S., 2002, Theologies in the Old Testament, T\&T Clark, London. Harari, Y.N., 2014, Sapiens: A brief history of humankind, Harvill Secker, London.

Horsley, R.A., 2003a, Religion and empire: People, power, and the life of the spirit, Fortress, Minneapolis, MN.

Horsley, R.A., 2003b, Jesus and empire: The kingdom of God and the new world disorder, Fortress, Minneapolis, MN.

Kennedy, P., 2006, A modern introduction to theology: New questions for old beliefs, I.B. Tauris, London.

LeDoux, J., 2019, The deep history of ourselves: The four-billion-year story of how we got conscious brains, Penguin, New York, NY.

Lewis-Williams, D., 2010, Conceiving God: The cognitive origin and evolution of religion, Thames \& Hudson, London.

Luttikhuizen, G.P., 2006, De veelvormigheid van het vroegste christendom, Damon, Budel.

McCoy, A.W., 2017, In the shadows of the American century: The rise and decline of US global power, Haymarket Books, Chicago, IL.

Noll, M.A., 1991, Between faith and criticism: Evangelicals, scholarship, and the bible, Apollos, Leicester.

Noort, E., 1994, Die Seevölker in Palästina, Palaestina Antiqua 8, Kok Pharos, Kampen.

Northcott, M., 2004, An angel directs the storm: Apocalyptic religion and American empire, I.B. Tauris, London.

Palmer, D., 2007, The origins of man, New Holland Publishers, London.

Pattison, G., 1998, The end of theology - And the task of thinking about God, SCM Press, London.

Rudwick, M., 2012, 'Charles Lyell. Earth's present as a key to its past', in A. Robinson (ed.), The scientists: An epic of discovery, pp. 82-87, Thames \& Hudson, London.

Skinner, B.J. \& Murck, B.W., 2011, The blue planet: An introduction to Earth system science, John Wiley \& Sons, Hoboken, NJ.

Sullivan, C., 2002, Rescuing Jesus from the Christians, Trinity Press International, Harrisburg.

Terreblanche, S., 2014, Western empires, Christianity, and the inequalities between the West and the rest, Penguin Books, Johannesburg.

Trocmé, É., 1997, The childhood of Christianity, SCM Press, London.

Van Rijn, R., 1655, Etch of David and Goliath, Rijksmuseum Amsterdam, viewed 14 April 2021, from http://hdl.handle.net/10934/RM0001.COLLECT.35763.

Vidal, G., 2004, Imperial America: Reflections on the United States of Amnesia, Clairview Books, Forest Row.

Viviers, H., 2008, "Who really "created"? Psalm 19 and Evolutionary Psychology in dialogue', Old Testament Essays 21(2), 546-563.

Wade, N., 2010, The faith instinct: How religion evolved and why it endures, Penguin Books, New York, NY

Weinert, F., 2009, Copernicus, Darwin, and Freud: Revolutions in the history and philosophy of science, Wiley-Blackwell, Chichester.

Wolpert, L., 2008, Six impossible things before breakfast: The evolutionary origins of belief, W.W. Norton \& Company, London.

Woolf, D., 2012, A global history of history, Cambridge University Press, Cambridge. 